\title{
Pre-breeding for diversification of primary gene pool and genetic enhancement of grain legumes
}

\author{
Shivali Sharma*, H. D. Upadhyaya, R. K. Varshney and C. L. L. Gowda
}

International Crops Research Institute for the Semi-Arid Tropics, Hyderabad, India

\section{Edited by:}

Scott Jackson, University of

Georgia, USA

Reviewed by:

Celine A. Hayden, Applied

Biotechnology Institute, USA

Andrew Scaboo, University of

Missouri, USA

*Correspondence:

Shivali Sharma, Scientist-Genetic

Resources, International Crops

Research Institute for the Semi-Arid

Tropics, RP-Grain Legumes,

Building \# 300, Patancheru 502324,

Hyderabad, Andhra Pradesh, India

e-mail: shivali.sharma@cgiar.org
The narrow genetic base of cultivars coupled with low utilization of genetic resources are the major factors limiting grain legume production and productivity globally. Exploitation of new and diverse sources of variation is needed for the genetic enhancement of grain legumes. Wild relatives with enhanced levels of resistance/tolerance to multiple stresses provide important sources of genetic diversity for crop improvement. However, their exploitation for cultivar improvement is limited by cross-incompatibility barriers and linkage drags. Pre-breeding provides a unique opportunity, through the introgression of desirable genes from wild germplasm into genetic backgrounds readily used by the breeders with minimum linkage drag, to overcome this. Pre-breeding activities using promising landraces, wild relatives, and popular cultivars have been initiated at International Crops Research Institute for the Semi-Arid Tropics (ICRISAT) to develop new gene pools in chickpea, pigeonpea, and groundnut with a high frequency of useful genes, wider adaptability, and a broad genetic base. The availability of molecular markers will greatly assist in reducing linkage drags and increasing the efficiency of introgression in pre-breeding programs.

Keywords: wild species, germplasm, pre-breeding, genomics, trait-specific

\section{INTRODUCTION}

Grain legumes are second in importance to human and animal diets after cereals and occupy an important place in the world's food and nutrition economy. Being the primary source of high quality dietary protein, grain legumes are important in alleviating protein deficiency and malnutrition prevailing among poor people in developing countries, as well as contributing significantly to global food and nutritional security. Further, grain legumes provide high quality nutritious fodder for animal consumption. In addition to food and fodder, the nitrogen fixing capacity of grain legumes decreases the need for direct application of $\mathrm{N}$-fertilizers and makes them an important component in cropping systems for improving and sustaining soil fertility and texture (Graham and Vance, 2003).

From the nutritional viewpoint, grain legumes are usually deficient in sulphur-containing amino acids-methionine, cysteine and tryptophan, but are rich in other essential amino acid, lysine. The reverse is true with cereals (Rockland and Radke, 1981). Therefore, the dietary mixture of cereals with legumes constitutes a source of balanced diet to the poor farmers in semi-arid tropical regions. In the past, the staple cereal crops, especially wheat, rice and maize, have received the highest research priority and considerable yield improvements were made in these crops. In contrast, grain legumes are under researched compared to cereals. Low yield potential coupled with biotic and abiotic stresses has further reduced their cultivation by the farmers. Recently, realizing the significance of grain legumes in improving nutrition and the livelihood of poor farmers, more research is now being carried out for their genetic amelioration by various institutes. The International Crops Research Institute for the Semi-Arid Tropics
(ICRISAT), Patancheru, India is working for the genetic improvement of three major grain legumes, i.e., chickpea (Cicer arietinum L.), pigeonpea (Cajanus cajan Millsp.), and groundnut (Arachis hypogaea L.).

Grain legumes are cultivated mostly in marginal lands under rainfed conditions, with low and unstable productivity (Kumar and van Rheenen, 2000). Their production is adversely affected by several biotic and abiotic stresses. Ascochyta blight, Botrytis gray mold, Fusarium wilt, and dry root rot in chickpea; Phytophthora blight, and sterility mosaic disease in pigeonpea; and early and late leaf spots (LLSs), rust and aflatoxin contamination in groundnut are the most important and widely distributed diseases affecting yield and quality. Besides, pod borer (Helicoverpa armigera L.), drought, heat, salinity, water-logging are the other important stresses potentially limiting their productivity worldwide. Grain legumes, including chickpea, pigeonpea and groundnut have a narrow genetic base, due to the bottlenecks associated with their evolution and domestication, as well as due to the replacement of locally adapted crop landraces by the genetically advanced modern varieties. Low grain legume productivity due to biotic/abiotic stresses coupled with limited genetic variation in the cultivated gene pool necessitates the identification and utilization of diverse germplasm sources to develop new high-yielding cultivars with a broad genetic base.

\section{GRAIN LEGUMES GENETIC RESOURCES}

Plant genetic resources are reservoirs of natural genetic variation and provide raw material for crop improvement programs. About 7.4 million germplasm accessions of different crops have been collected and/or assembled and conserved in over 1750 ex 
situ genebanks worldwide (FAO, 2010) and the grain legumes constitute the second largest collection (15\%) after cereals (45\%). Globally, $\sim 1.1$ million grain legume germplasm accessions are conserved in different genebanks, of which ICRISAT genebank holds $\sim 50,000$ accessions including cultivated and wild relatives of chickpea $(20,267$ accessions), pigeonpea $(13,771$ accessions), and groundnut (15,445 accessions) from 133 countries. Besides ICRISAT, other major genebanks holding grain legume germplasm are the National Bureau of Plant Genetic Resources (NBPGR), New Delhi, India (16,881 Cicer, 12,900 Cajanus and 14,593 Arachis accessions); the International Centre for Agricultural Research in Dry Areas (ICARDA), Aleppo, Syria (13,818 Cicer accessions); the United States Department of Agriculture (USDA), USA (9964 Arachis accessions); and the Directorate of Groundnut Research (DGR), Junagadh, India (8934 Arachis accessions) (updated report based on species in http://apps3.fao.org/wiews/germplasm_query.htm?i_l=EN).

At present, emphasis is on conserving accessions safely with duplication both within and outside the CGIAR. At global level, the Svalbard Global Seed Vault has been established in the Norwegian island of Spitsbergen to store seed samples of a wide variety of plant species in an underground cavern. This seed vault will provide an insurance against the loss of seeds in genebanks, as well as a refuge for seeds in the case of large-scale regional or global crises. Over the last 5 years, $>780,000$ seed samples belonging to about 840 genera have been deposited in this vault of which about 170,000 accessions belong to 19 legume genera/species (http://www.nordgen.org/sgsv/index.php?app=data_unit\&unit= sgsv_by_species\&PHPSESSID=1hoc3n9kkdmng79o5vlqmsgs25).

\section{USE OF GERMPLASM IN GRAIN LEGUME IMPROVEMENT}

Surprisingly, in spite of large collections, only a few germplasm accessions $(<1 \%)$ have been utilized in crop improvement programs such as in wheat (Dalrymple, 1986), maize (Cantrell et al., 1996), spring barley (Vellve, 1992), soybean (Mikel et al., 2010), and other grain legumes (Kumar et al., 2004). India has one of the largest grain legume breeding programs and has released about 230 cultivars of chickpea, pigeonpea, lentil, black gram, and green gram through hybridization and selection (data up to 2003). Pedigree analysis of these cultivars revealed that $\mathrm{Pb}-7$ in chickpea, T-1 and T-190 in pigeonpea, L-9-12 in lentil, T-9 in black gram, and T-1 in green gram were the most frequently used parents (Kumar et al., 2004). In ICRISAT, which has the largest germplasm collections of chickpea, pigeonpea and groundnut, the breeding programs have used only 91 chickpea $(0.4 \%$ of total 20,267 accessions), 54 pigeonpea ( $0.4 \%$ of total 13,771 accessions) and 171 groundnut (1.1\% of total 15,445 accessions) germplasm accessions to develop advanced breeding lines. Further, the increase in accession numbers in genebanks and lack of corresponding increase in their utilization by the crop improvement scientists also indicate that the collections are not being utilized to their full potential (Marshall, 1989). As a global responsibility, ICRISAT's genebank has supplied over 303,000 samples of grain legumes, which includes 131,924 samples of chickpea, 71,826 samples of pigeonpea, and 99,325 samples of groundnut accessions to scientists across 136 countries. Besides this, over 370,000 samples of these legumes have also been distributed to researchers within ICRISAT during 1974-June 2013. Some of the germplasm accessions supplied from ICRISAT genebank have been released directly as varieties by NARS such as 15 chickpea germplasm accessions released as varieties in 15 countries, 10 pigeonpea germplasm accessions in seven countries and 11 groundnut germplasm accessions in 15 countries (Table $\mathbf{1}$ ). These varieties have greatly benefited the farmers by contributing to increase in production and productivity in these countries. However, the pattern of demand and consequent supply has shown a greater demand for a few specific germplasm accessions. In a period of 35 years, in chickpea, two accessions, ICC 4918 and ICC 4973 were supplied over 350 times, and four accessions more than 200 times. In pigeonpea, one accession, ICP 7035 was supplied 330 times, and seven accessions more than 200 times. Similarly, in groundnut, one accession, ICG 799 was supplied over 300 times, and five accessions about 200 times. Further, 3740 chickpea, 3088 pigeonpea and 1018 groundnut accessions have not been requested at all, while 7339 chickpea, 7001 pigeonpea and 7582 groundnut accessions have been supplied less than five times (as on 30 May 2013).

\section{REASONS FOR LOW USE OF GERMPLASM}

The factors responsible for low use of germplasm in crop improvement programs are the large size of germplasm collections, the breeders' preference for working collections, and the linkage drag associated with utilizing wild relatives in crop improvement programs. Large germplasm collections of most crops, including grain legumes, poses problem for their meaningful multi-locational evaluation. Thus, there is a lack of information on traits of economic importance, which often shows high genotype $\times$ environment interaction, for large number of germplasm accessions. This creates a problem for the breeders to select the appropriate genetic diversity for use in their breeding programs. However, strategies are now available to overcome the problems associated with the large size of germplasm collections. This includes the development of representative smallsized subsets such as core (Frankel and Brown, 1984) and mini core (Upadhyaya and Ortiz, 2001) collections that contain the majority of allelic diversity. Besides large size, there are apprehensions among breeders about poor adaptability of germplasm and linkage drag. Linkage drag is the most important factor responsible for low use of germplasm in crop improvement and is the major reason for the need for pre-breeding. While using unknown and wild germplasm, comparatively more efforts, time and resources are required to break undesirable linkage drag during the development process, particularly for regional adaptability to climates, crop management, biotic and abiotic stresses, and overall agronomic performance. This makes the breeding program comparatively more lengthy and cumbersome (Figure 1). For these reasons, breeders use their working collection in breeding programs which results in re-circulation of same genotype and hence narrow genetic base of the released cultivars. Nevertheless, the above reservations and over cautiousness toward linkage drag has resulted in continuous narrowing down of genetic variability among modern cultivars, with implications for survival from several biotic and abiotic stresses. 
Table 1 | List of chickpea, pigeonpea and groundnut germplasm accessions directly released as varieties for cultivation.

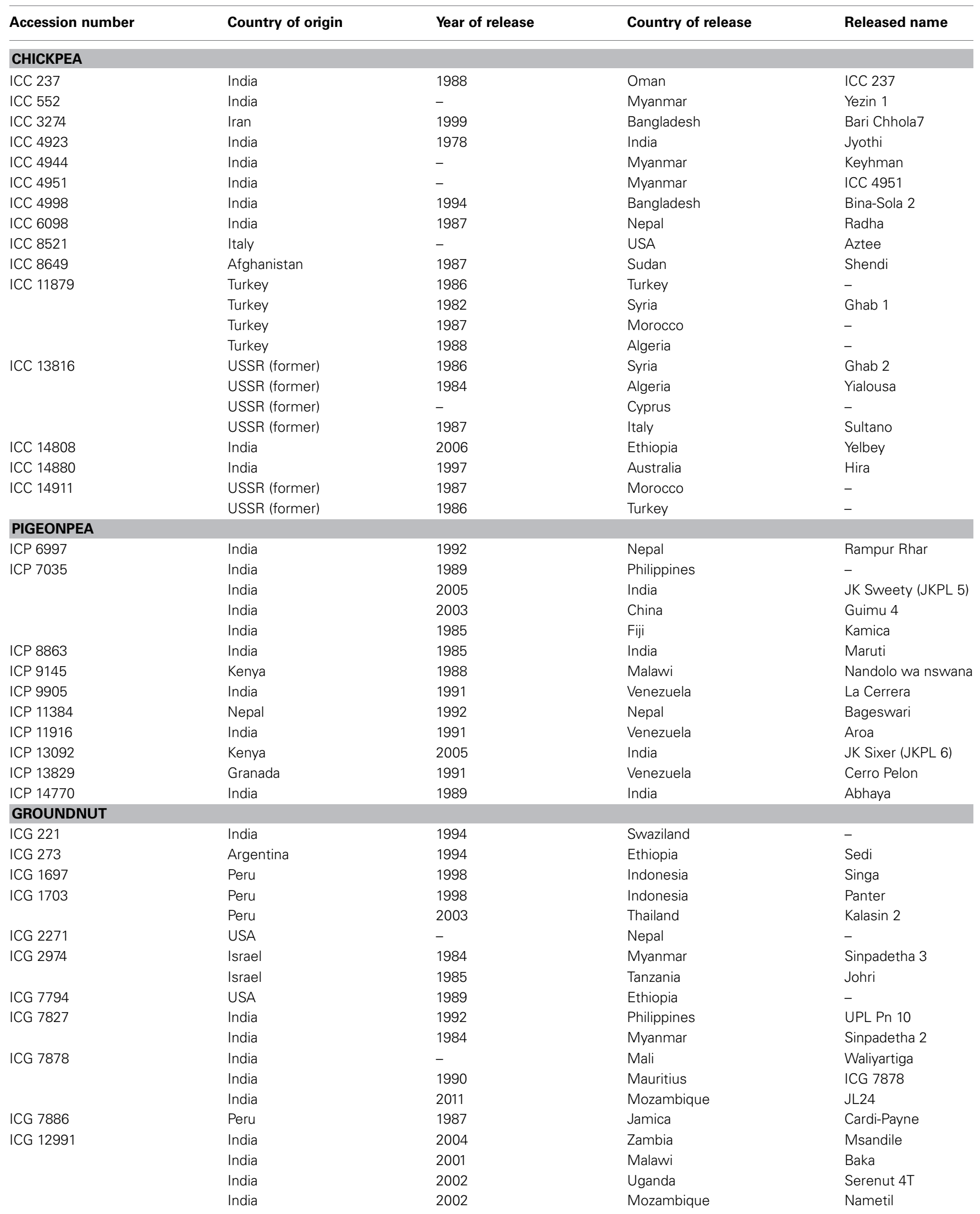




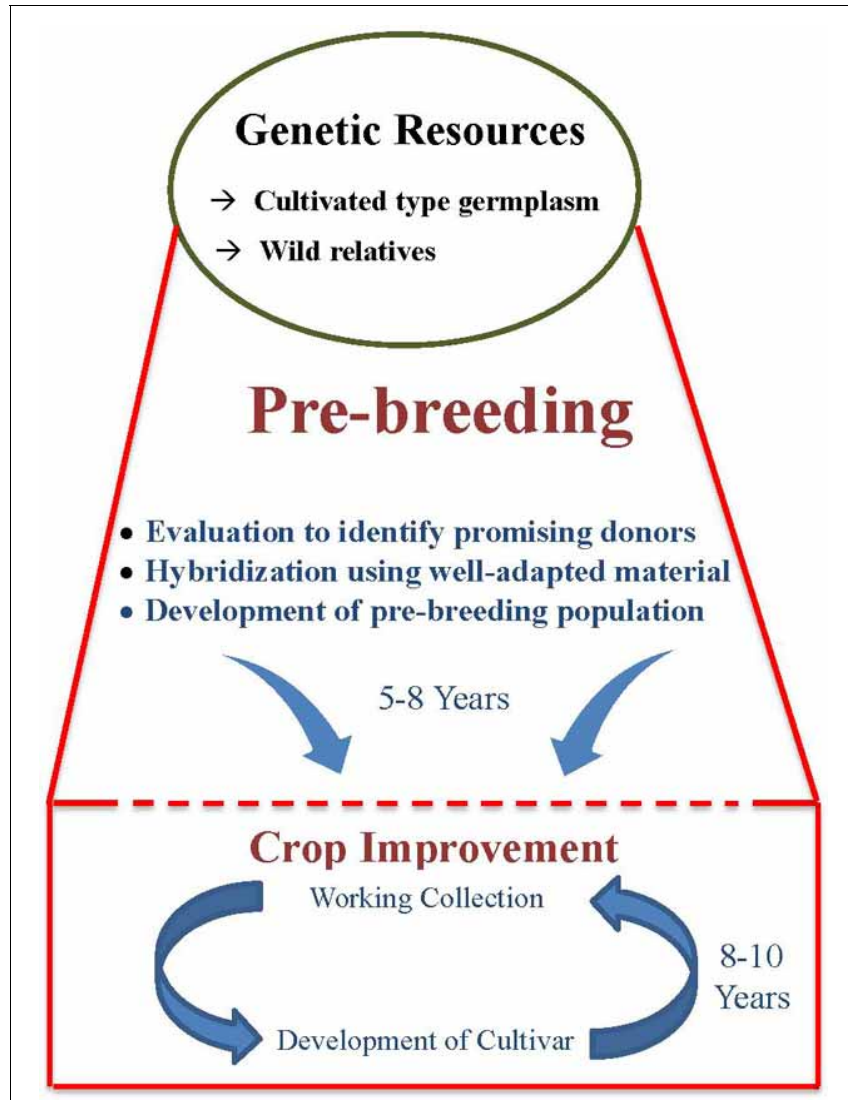

FIGURE 1 | Pre-breeding as a bridge between genetic resources and crop improvement.

\section{PRE-BREEDING FOR ACCESSING NOVEL GENES}

The success of any crop improvement program depends on the availability of sufficient genetic variability, but this variability must be in conventionally usable form. The variability available in any crop germplasm conserved in genebanks for present and future use belongs broadly to the following three groups:

1. Cultivated type

2. Cross-compatible wild type

3. Cross-incompatible wild type

The genetic variability in cultivated type germplasm is either in poor agronomic background or in genetic background not adapted to the breeding or target climate for its direct use in conventional breeding programmes. The exploitation of genetic variability in wild species for cultivar improvement is hindered mainly by linkage drag and different incompatibility barriers between cultivated and wild species. Under such situations, prebreeding offers a unique tool to enhance the use of genetic variability present both in cultivated and wild type germplasm.

Pre-breeding involves all the activities associated with identification of desirable traits and/or genes from unadapted germplasm (donor) that cannot be used directly in breeding populations (exotic/wild species), and to transfer these traits into well-adapted genetic backgrounds (recipients) resulting in the development of an intermediate set of material which can be used readily by the plant breeders in specific breeding programmes to develop new varieties with a broad genetic base (Figure 1).

\section{IDENTIFICATION OF TRAIT-SPECIFIC GERMPLASM ACCESSIONS Cultivated type germplasm}

Enormous efforts are needed to evaluate germplasm for traits of economic importance, as well as to screen for biotic and abiotic stress related traits through reliable and standardized techniques for identifying potential donors. Owing to the large size of germplasm collections, this becomes a costly and resourcedemanding task. Following the concept of Frankel and Brown (1984) for sampling diversity, a number of small-sized subsets such as core (10\% of the entire collection in size) and mini core ( $10 \%$ of core or $1 \%$ of entire collection) collections representing the diversity of entire collections have been developed in chickpea, pigeonpea and groundnut (Table 2). Due to their small size, these collections, especially mini core collections, provide an easy means to evaluate these collections across multilocations and to identify promising germplasm accessions as new and potential donors for various traits. Over 90 sets of mini core collections of SAT legumes have been shared by ICRISAT genebank with researchers in 20 countries. Evaluation of germplasm including core/mini core collections globally has resulted in the identification of new and diverse trait-specific germplasm accessions for agronomic and nutritional traits, as well as for resistance/tolerance to various biotic/abiotic stresses (reviewed in Upadhyaya et al., 2010). For example, new and promising sources for early maturity, large seed size, yield and component traits, and for nutrition-related traits, are now available for improvement of chickpea, pigeonpea and groundnut (Table 3). Similarly, for abiotic/biotic stresses, new sources of tolerance/resistance have been identified in chickpea, pigeonpea and groundnut (Table 4). For example, in chickpea, in addition to the well-known drought tolerant accession, ICC 4958, new sources of drought tolerance have been identified using different techniques (Table 4); ICC 13124 has the highest drought tolerance efficiency (DTE), lowest drought susceptibility index (DSI) and the highest harvest index (HI) and has been identified as the most drought tolerant accession (Parameshwarappa and Salimath, 2008; Parameshwarappa et al., 2010). Recently, to combat the effect of climate change on grain legume production, new and diverse sources of heat tolerance (Krishnamurthy et al., 2011a; Upadhyaya et al., 2011a), herbicide tolerance (Tar'an et al., 2010) and accessions with greater biological nitrogen fixation (BNF) capacity (Biabani et al., 2011) for chickpea and water-logging tolerant accessions for pigeonpea improvement (Krishnamurthy et al., 2011b) (Table 4) have also been identified.

\section{Wild type germplasm}

Wild species are the reservoir of many useful genes/alleles as they have evolved under natural selection to survive climate extremes. Wild species of Cicer, Cajanus, and Arachis have been extensively screened and several of them were reported to have very high level of resistance/tolerance to various stresses. Among wild Cicer species, C. bijugum, C. judaicum, and C. pinnatifidum are 
Table 2 | Core and mini core collections as reported in chickpea, pigeonpea and groundnut.

\begin{tabular}{|c|c|c|c|c|}
\hline Reduced subset & Accessions used (No.) & Collection & $\begin{array}{l}\text { Accessions in constituted } \\
\text { collection (No.) }\end{array}$ & References \\
\hline \multirow[t]{3}{*}{ Chickpea } & 16,991 & Core & 1956 & Upadhyaya et al., 2001a \\
\hline & 1002 & Core & 158 & Kibret, 2012 \\
\hline & - & Kabuli core & 103 & Pouresmael et al., 2009 \\
\hline \multirow[t]{2}{*}{ Pigeonpea } & 12,153 & Core & 1290 & Reddy et al., 2005 \\
\hline & 1290 & Mini core & 146 & Upadhyaya et al., 2006a \\
\hline \multirow[t]{3}{*}{ Groundnut } & 630 & Valencia core & 77 & Dwivedi et al., 2008b \\
\hline & 7432 & Core & 831 & Holbrook et al., 1993 \\
\hline & 1704 & Mini core & 184 & Upadhyaya et al., 2002 \\
\hline
\end{tabular}

the most important sources having the highest levels of resistance/tolerance to multiple stresses (reviewed in Gaur et al., 2009; Sharma et al., 2013). Wild Cajanus species especially, C. scarabaeoides, C. acutifolius, C. platycarpus, C. reticulatus, C. sericeus, and C. albicans provide resistance to pod borer, Helicoverpa armigera (Rao et al., 2003; Sujana et al., 2008; Sharma et al., 2009). Evaluation of wild Cajanus species has identified new sources of resistance to Alternaria blight, Phytophthora blight, sterility mosaic virus, pod fly and nematodes and tolerance to salinity, drought, and photoperiod insensitivity (reviewed in Upadhyaya et al., 2013). Good sources of resistance for bruchids (Callosobrochus maculatus) have also been identified in C. scarabaeoides, C. acutifolius, and C. platycarpus (Jadhav et al., 2012). Similarly, wild Arachis species harbor very high levels of resistance/tolerance to many biotic/abiotic stresses (reviewed in Dwivedi et al., 2008a; Upadhyaya et al., 2012a). These wild species are the potential donors to develop genome-wide introgression (GWI) lines for the genetic amelioration of chickpea, pigeonpea and groundnut.

\section{PRE-BREEDING FOR GRAIN LEGUME GENETIC ENHANCEMENT}

The success of any pre-breeding program depends mainly upon three factors: (1) identification of promising donor with good expression of the trait; (2) type of germplasm (Cultivated/crosscompatible wild type/cross-incompatible wild type); and (3) agronomic performance of the donors. New and diverse sources of variation for agronomic and nutrition-related traits and resistant/tolerant sources for biotic/abiotic stresses are now available both in cultivated and wild type germplasm and can be utilized to develop new pre-breeding populations having greater variability for various traits. In the past, a few promising wild type accessions have been utilized by some researchers for the improvement of chickpea, pigeonpea and groundnut and are given hereunder.

\section{Pre-breeding for biotic/abiotic stresses}

Chickpea. Of the eight annual wild Cicer species, only C. reticulatum is readily crossable with cultivated chickpea resulting in fertile hybrid. The exploitation of the remaining seven annual wild Cicer species requires specialized techniques such as the application of growth hormones, embryo rescue, ovule culture, and tissue culture techniques (Badami et al., 1997; Mallikarjuna, 1999; Lulsdorf et al., 2005; Mallikarjuna and Jadhav, 2008). Utilization of C. reticulatum accession, ILWC 119 in crossing programme has resulted in the development of two cyst nematode resistant chickpea germplasm lines ILC 10765 and ILC 10766 (Malhotra et al., 2002). Beneficial traits such as cold tolerance and a high degree of resistance to wilt, foot rot, root rot, and Botrytis gray mold have also been introgressed from C. reticulatum and C. echinospermum into cultivated chickpea (ICARDA, 1995; Singh et al., 2005; Ramgopal et al., 2012). Using novel techniques, interspecific hybrids have been produced between $C$. arietinum $\times C$. judaicum (Verma et al., 1990; Verma and RaviSandhu, 1995; Singh et al., 1999), C. arietinum $\times$ C. pinnatifidum (Verma et al., 1990; Badami et al., 1997; Mallikarjuna, 1999; Mallikarjuna and Jadhav, 2008), C. arietinum $\times$ C. cuneatum (Singh and Singh, 1989), and C. arietinum $\times$ C. bijugum (Verma et al., 1990; Singh et al., 1999; Mallikarjuna et al., 2007) to introgress desirable alien genes from these cross-incompatible wild Cicer species into cultivated chickpea. These interspecific hybrids have contributed significantly toward the development of genomic resources for chickpea improvement.

Pigeonpea. Wild Cajanus species, especially the cross-compatible secondary gene pool species, have been used for the genetic improvement of pigeonpea and the most significant achievement includes the development of unique cytoplasmic-nuclear male sterility system (CMS). The CMS systems have been developed with cytoplasm derived from wild Cajanus species namely 
Table 3 | Promising germplasm accessions for agronomic and nutrition-related traits in chickpea, pigeonpea and groundnut.

\begin{tabular}{|c|c|c|c|}
\hline Traits & Chickpea & Pigeonpea & Groundnut \\
\hline Early maturity & $\begin{array}{l}28 \text { accession (ICC\# 16641, 16644, 11040, 11180, } \\
\text { and 12424; Upadhyaya et al., 2007a)* }\end{array}$ & $\begin{array}{l}8 \text { accession (ICP\# 14900, 1156, } \\
\text { 14471, 14903, and 16309; } \\
\text { Upadhyaya et al., 2010) }\end{array}$ & $\begin{array}{l}21 \text { accession (ICG\# 4558, 4890, } \\
\text { 9930, 11605, and 5512; } \\
\text { Upadhyaya et al., 2006b) }\end{array}$ \\
\hline Large seed & $\begin{array}{l}11 \text { accessions (ICC\# 14190, 14194, 7345, 17452, } \\
\text { 19189, and 17109; Gowda et al., 2011) } \\
4 \text { accessions (ICC\# 14199, 14197, 14203, and } \\
12033 \text {; Kaul et al., 2007) } \\
9 \text { accessions (ICC\# 17457, 17452, 19189, 17456, } \\
\text { and 18591; Kashiwagi et al., 2007) }\end{array}$ & $\begin{array}{l}3 \text { accessions (ICP\# 14976, } \\
\text { 13359, and 13139; Upadhyaya } \\
\text { et al., 2010) }\end{array}$ & $\begin{array}{l}12 \text { accessions (ICG\# 2381, 5016, } \\
\text { 5051, 5745, and 5662; Upadhyaya } \\
\text { et al., 2010) }\end{array}$ \\
\hline $\begin{array}{l}\text { Yield and component } \\
\text { traits }\end{array}$ & $\begin{array}{l}39 \text { accessions (ICC\# 6122, 8474, 8155, 12034, and } \\
4871 \text {; Upadhyaya et al., 2007b) } \\
8 \text { accessions (ICC\# 13124, 12654, 9848, 6279, } \\
5879 \text {, and 10341; Parameshwarappa et al., } \\
2011 \text { a,b) } \\
6 \text { accessions (ICC\# 14778, 6279, 4567, 4533, } \\
\text { 1397, and 12328; Meena et al., 2010) }\end{array}$ & $\begin{array}{l}4 \text { accessions (ICP\# 8860, } 11230 \text {, } \\
4167 \text {, and 8602; Upadhyaya et al., } \\
\text { 2010) }\end{array}$ & $\begin{array}{l}60 \text { accessions (ICG\# 4, 29, 3443, } \\
\text { 14161, 11188, 7140, and 2918; } \\
\text { Upadhyaya et al., 2005) }\end{array}$ \\
\hline Protein content (>30\%) & - & $\begin{array}{l}6 \text { accessions (ICP\# 4575, 7426, } \\
8266,11823,12515 \text { and } 12680 ; \\
\text { Upadhyaya et al., 2013) }\end{array}$ & $\begin{array}{l}18 \text { accessions (ICG \# 36, 5779, } \\
\text { 3421, 3584, and 2019; Upadhyaya } \\
\text { et al., 2012b) }\end{array}$ \\
\hline Oil content (>50\%) & - & - & $\begin{array}{l}18 \text { accessions (ICG \# 442, 397, } \\
5779,4955 \text { and 14710; } \\
\text { Upadhyaya et al., 2012b) }\end{array}$ \\
\hline Oleic acid $(\geq 60 \%)$ & - & - & $\begin{array}{l}18 \text { accessions (ICG \# 6022, } 12625 \\
\text { and } 11088 \text { in subsp. fastigiata; } \\
\text { and ICG\# 2381, 10185, 15419, } \\
\text { 12276, } 7243 \text { and } 6766 \text { in subsp. } \\
\text { hypogaea; Upadhyaya et al., } \\
\text { 2012b) }\end{array}$ \\
\hline
\end{tabular}

${ }^{*}$ A few promising accessions are given in parenthesis with reference.

C. sericeus (Ariyanayagam et al., 1995), C. scarabaeoides (Tikka et al., 1997; Saxena and Kumar, 2003), C. volubilis (Wanjari et al., 2001), C. cajanifolius (Saxena et al., 2005), C. lineatus (Saxena et al., 2010), and C. platycarpus (Mallikarjuna et al., 2011a). For pigeonpea improvement, the potential for genetic introgression of salinity tolerance from wild relative, Atylosia albicans to cultivated pigeonpea has been demonstrated in the $F_{1}$ (Subbarao et al., 1990). Further, utilization of C. acutifolius as the pollen parent has resulted in the development of advanced generation population having resistance to pod borer (Mallikarjuna et al., 2007), variation in seed color and high seed weight. For Phytophthora blight, resistant genes have been transferred from C. platycarpus into cultivated pigeonpea and the resistant plants identified at seedling stage showed resistance across all stages of their life cycle (Mallikarjuna et al., 2005).
Groundnut. Utilization of wild Arachis species following interspecific hybridization has resulted in the development of many elite germplasm lines and cultivars with improved level of resistance to diseases and insect-pests. At ICRISAT, several elite lines have been developed with desirable characters transferred from wild Arachis species such as ICGV 86699 (Reddy et al., 1996) with multiple pest resistance, ICGV 87165 (Moss et al., 1998) with multiple disease and insect resistance, ICGV 99001 and 99004 with resistance to LLS, and ICGV 99003, and 99005 resistant to rust (Singh et al., 2003). Varieties such as Spancross (Hammons, 1970), Tamnut 74 (Simpson and Smith, 1975), Coan (Simpson and Starr, 2001), NemaTAM (Simpson et al., 2003), ICGV-SM 85048 (Nigam et al., 1998), and ICGV-SM 86715 (Moss et al., 1998), having a genetic base from wild Arachis species, were released for cultivation, mostly in USA. The development and 
Table 4 | New sources of tolerance/resistance to abiotic/biotic stresses for chickpea, pigeonpea and groundnut improvement.

\begin{tabular}{|c|c|c|}
\hline Traits & Promising germplasm & References \\
\hline \multicolumn{3}{|l|}{ CHICKPEA } \\
\hline \multirow[t]{5}{*}{ Drought } & $\begin{array}{l}\text { Root length density: } 9 \\
\text { accessions (ICC\# } 8261 \\
\text { 10885, 16796, } 13816 \text { and } \\
\text { 13599)* }\end{array}$ & $\begin{array}{l}\text { Kashiwagi et al., } \\
2005\end{array}$ \\
\hline & $\begin{array}{l}\text { Root depth: } 9 \text { accessions } \\
\text { (ICC\# 3512, 15697, 13523, } \\
\text { 1356, and 4872) }\end{array}$ & $\begin{array}{l}\text { Kashiwagi et al., } \\
2005\end{array}$ \\
\hline & $\begin{array}{l}\text { SPAD Chlorophyll Meter } \\
\text { Reading (SCMR): } 4 \\
\text { accessions (ICC\# 16374, } \\
\text { 1422, 16903, and 10945) }\end{array}$ & $\begin{array}{l}\text { Kashiwagi et al., } \\
2006,2010\end{array}$ \\
\hline & $\begin{array}{l}\text { Canopy temperature: } 3 \\
\text { accessions (ICC\# 3325, 867, } \\
\text { and 14799) }\end{array}$ & $\begin{array}{l}\text { Kashiwagi et al., } \\
2008\end{array}$ \\
\hline & $\begin{array}{l}\text { Terminal drought: } 5 \\
\text { accessions (ICC\# 867, 1923, } \\
\text { 9586, } 12947 \text { and 14778) }\end{array}$ & $\begin{array}{l}\text { Krishnamurthy et al., } \\
2010\end{array}$ \\
\hline \multirow[t]{3}{*}{ Salinity } & $\begin{array}{l}10 \text { accessions (ICC\# } 10755 \text {, } \\
\text { 13124, 13357, 15406, and } \\
15697)\end{array}$ & Serraj et al., 2004 \\
\hline & $\begin{array}{l}15 \text { accessions }(5003,15610 \\
1431,4593, \text { and } 12155)\end{array}$ & Vadez et al., 2007 \\
\hline & $\begin{array}{l}12 \text { accessions }(9942,6279 \\
11121,456 \text { and } 14799)\end{array}$ & $\begin{array}{l}\text { Krishnamurthy et al., } \\
\text { 2011c }\end{array}$ \\
\hline \multirow[t]{2}{*}{ Heat } & $\begin{array}{l}18 \text { accessions (ICC\# 456, 637, } \\
1205,3362 \text {, and 3761) }\end{array}$ & $\begin{array}{l}\text { Krishnamurthy et al., } \\
\text { 2011a }\end{array}$ \\
\hline & $\begin{array}{l}10 \text { accessions }(14346,5829 \\
6121,13124 \text { and } 14284)\end{array}$ & $\begin{array}{l}\text { Upadhyaya et al., } \\
2011 a\end{array}$ \\
\hline $\begin{array}{l}\text { Herbicide } \\
\text { (imazethapyr and } \\
\text { imazamox) }\end{array}$ & $\begin{array}{l}4 \text { accessions (ICC\# 2242, } \\
2580,3325 \text { and ILC 4279) }\end{array}$ & Tar'an et al., 2010 \\
\hline Multiple disease & $\begin{array}{l}18 \text { accessions (ICC\# 1710, } \\
2242,2990,11284, \text { and } \\
12328 \text { ) }\end{array}$ & Pande et al., 2006 \\
\hline \multicolumn{3}{|l|}{ PIGEONPEA } \\
\hline Water-logging & $\begin{array}{l}24 \text { accessions (ICP\# 1279, } \\
7057,7148,10397 \text {, and 16309) }\end{array}$ & $\begin{array}{l}\text { Krishnamurthy et al., } \\
2011 \text { b }\end{array}$ \\
\hline Salinity & $\begin{array}{l}16 \text { accessions (ICP\# 8860, } \\
7426,14722,11477 \text {, and } 6128)\end{array}$ & $\begin{array}{l}\text { Srivastava et al., } \\
2006\end{array}$ \\
\hline $\begin{array}{l}\text { Combined } \\
\text { resistance for } \\
\text { Fusarium wilt } \\
\text { and sterility } \\
\text { mosaic }\end{array}$ & $\begin{array}{l}6 \text { accessions (ICP\# 6739, } \\
8860,11015,13304,14638 \\
\text { and } 14819)\end{array}$ & Sharma et al., 2012 \\
\hline \multicolumn{3}{|l|}{ GROUNDNUT } \\
\hline \multirow[t]{2}{*}{ Drought } & $\begin{array}{l}18 \text { accessions (ICG\# } 14523 \\
6766,7243,862, \text { and } 6654)\end{array}$ & Upadhyaya, 2005 \\
\hline & $\begin{array}{l}30 \text { accessions }(11088,12697 \\
8751,3140, \text { and } 3584)\end{array}$ & Hamidou et al., 2011 \\
\hline
\end{tabular}

(Continued)
Table 4 | Continued

\begin{tabular}{|c|c|c|}
\hline Traits & Promising germplasm & References \\
\hline $\begin{array}{l}\text { Low } \\
\text { temperature }\end{array}$ & $\begin{array}{l}15 \text { accessions (ICG\# 12625, } \\
7898,11130,6148, \text { and } 7013 \text { ) }\end{array}$ & $\begin{array}{l}\text { Upadhyaya et al., } \\
2009\end{array}$ \\
\hline Salinity & $\begin{array}{l}14 \text { accessions (ICG\# 5195, } \\
442,7283,1711 \text {, and 2106) }\end{array}$ & Srivastava, 2010 \\
\hline $\begin{array}{l}\text { Rhizoctonia limb } \\
\text { rot resistant }\end{array}$ & $\begin{array}{l}6 \text { accessions (PI\# } 343398 \\
\text { 343361, 288178, 331326, } \\
\text { 497351, and 274193) }\end{array}$ & Franke et al., 1999 \\
\hline
\end{tabular}

\begin{tabular}{lll}
\hline Late leaf spot & $\begin{array}{l}7 \text { accessions (ICG\# 12625, } \\
\text { 11426, 12672, 13787, 14475, } \\
\text { 2857, and 8760) }\end{array}$ & Kusuma et al., 2007 \\
\hline Rust & $\begin{array}{l}22 \text { accessions (ICG 9809, } \\
11088,11426,13787, \text { and }\end{array}$ & \\
& $8760)$ & Kusuma et al., 2007
\end{tabular}

A. flavus 6 accessions (ICG\# 14985, Kusuma et al., 2007 $3673,6025,12625,13787$, and 8760)

20 accessions $(6813,12370$, Jiang et al., 2010 4750,4156 , and 12697)

Bud necrosis $\quad 4$ accessions (ICG\# 875, 928, Ahmed, 2008
1668 , and 14466)

Combined 5 accessions (PI\# 274193, $\quad$ Damicone et al., resistance to 497599, 458619, 468195, and 2010 Sclerotinia 259796)

blight, pepper

spot and web

blotch

${ }^{*} A$ few promising accessions are given in parenthesis.

utilization of synthetic amphiploids such as TxAG-6 with large genetic variation (Simpson et al., 1993) has made possible the transfer of resistance genes from wild species into cultivated groundnut. TxAG-6 is a synthetic amphiploid derived from crossing an AA-genome donor hybrid (A. cardenasii $\times$ A. diogoi) with a BB genome species, A. batizocoi, followed by colchicine treatment of the sterile triploid to produce fertile hexaploid, TxAG-6 (Simpson et al., 1993). This amphiploid has been synthesized using species that are not in the direct lineage of the cultivated groundnut. However, it is crossable with the cultivated groundnut and produced fertile progenies, thus proving useful for introducing genetic variability into the cultigen. Using this amphiploid in crossing programs with cultivated groundnut has resulted in the release of two cultivars, Coan and NemaTAM, carrying genes for root-knot nematode ( $M$. arenaria) resistance from A. cardenasii (Simpson and Starr, 2001; Simpson et al., 2003).

\section{Pre-breeding for improvement of agronomic and nutrition-related traits}

Besides resistant sources, studies also indicated the possibility of improving agronomic traits, including yield, through introgression of genes from the wild species into the cultigens. In 
chickpea, by hybridizing C. reticulatum and C. echinospermum with cultigen, Singh and Ocampo (1997) generated high-yielding recombinant lines without any known undesirable traits from the wild species. In a similar study, introgressing wild genes from C. reticulatum into cultivated chickpea generated nine genotypes with high yield potential, resistance to soil-borne diseases and adaptation to water-limited environments. Three lines BG 1100, BG 1101, and BG 1103 produced 20\% higher seed yield than the best-adapted cultivars and were resistant to Fusarium wilt (Fusarium oxysporum f.sp. ciceris) (Yadav et al., 2004). Interspecific derivatives possessing a high degree of resistance to diseases such as wilt, root rot and foot rot, and high yield, have been obtained from $C$. arietinum $\times C$. reticulatum crosses (Singh et al., 2005). In ICRISAT, using two C. reticulatum accessions (110-113 days to 50\% flowering, 143-150 days to maturity, 12-16 g 100-seed weight) in a hybridization program, several progenies were selected which took 8-21 days less to flower, 6-33 days less to mature, with 20-103\% larger seeds, and $97-217 \%$ greater seed yield than respective cultivated (C. arietinum) parent (Upadhyaya, 2008). From C. arietinum $\times$ C. judaicum cross, a pre-breeding line IPC 71 having high number of primary branches, more pods per plant and green seeds has been developed for use in chickpea improvement programs (Chaturvedi and Nadarajan, 2010).

Further, utilization of wild Cajanus species has also contributed significantly toward the improvement of agronomic performance and nutritional quality of cultivated pigeonpea. A high protein line, ICPL 87162 was developed from the cross C. cajan $\times$ C. scarabaeoides (Reddy et al., 1997). This line contains 30-34\% protein content compared to control cultivar (23\% protein). Breeding lines with high protein content have also been developed from C. sericeus, C. albicans, and C. scarabaeoides. Utilization of wild Cajanus species has resulted in the development of several lines such as HPL 2, HPL 7, HPL 40, and HPL 51 having high protein and seed weight (Saxena et al., 1987). Recently, scientists at ICRISAT have generated segregants with up to $20.4 \mathrm{~g}$ 100 -seed weight from the cross between cultivated pigeonpea, ICPL 85010 (10.5 g 100-seed weight) and C. acutifolius, ICP 15605 (2.2 g 100-seed weight) (Figure 2).

Similarly in groundnut, by using an amphiploid TxAG-6 [(Arachis cardenasii $\times A$. diogoi $) \times A$. batizocoi $]$ with very low 100 -seed weight $(\sim 12 \mathrm{~g})$ and poor pod yield $\left(2-5 \mathrm{~g} \mathrm{plant}^{-1}\right)$, breeding lines have been developed. These have higher 100 -seed

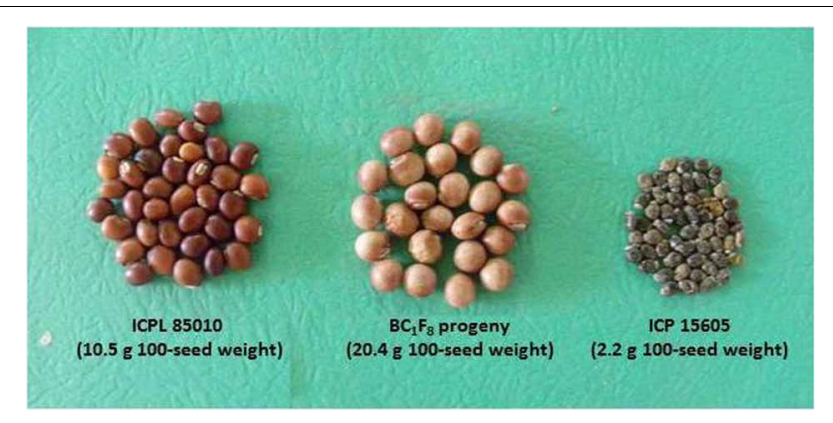

FIGURE 2 | Improvement of seed traits in cultivated pigeonpea by using Cajanus acutifolius. weight (up to $95 \mathrm{~g}$ ) compared to $32 \mathrm{~g}$ of control cultivar TMV 2 and 23-68\% more pod yields than TMV $2\left(3343 \mathrm{~kg} \mathrm{ha}^{-1}\right)$. They also have $10-50 \%$ more pod yield than the high yielding control cultivar ICGV $91114\left(3741 \mathrm{~kg} \mathrm{ha}^{-1}, 49 \mathrm{~g} 100\right.$-seed weight $^{-1}$ ) (Upadhyaya, 2008). This demonstrates that the novel alleles of wild relatives that were considered to be lost in evolution to cultivated types could still be used to enhance the important agronomic and nutrition-related traits in cultivars.

\section{PRE-BREEDING FOR CLIMATE SMART GRAIN LEGUME CROPS}

The emerging threat to global crop production is climate variability, leading to frequent droughts as a result of erratic rainfall, high temperature prevalence, water-logging, increased soil salinity, and emergence of new insect-pests and diseases. Due to climate change, several areas are now becoming unfit for cultivation of traditional crops. To cope up with this situation, there is a need to breed new crop cultivars with a broad genetic base capable of withstanding frequent climatic fluctuations. In grain legumes, emerging threats due to climate change involves dry root rot (Rhizoctonia bataticola) and Ascochyta blight in chickpea and Phytopthora and Alternaria blight in pigeonpea. Frequent droughts coupled with high temperature during flowering to pod filling stage would result in heavy incidence of dry root rot whereas cooler temperature with high humidity are associated with high incidence of Ascochyta blight in chickpea (Pande et al., 2010). In pigeonpea, erratic and heavy rainfall (>300 $\mathrm{mm}$ in 6-7 days) leading to temporary flooding has resulted in an outbreak of Phytophthora blight in Deccan Plateau of India (Sharma et al., 2006). Recently, Alternaria blight of pigeonpea is becoming a serious threat in semi-arid tropics due to the untimely rainfall. Changing climatic conditions resulting in high rainfall will favor foliar diseases and some soilborne pathogens such as Phytophthora, Pythium, Rhizoctonia solani, and Sclerotium rolfsii whereas low rainfall resulting in decreased moisture will lead to the high incidence of Fusarium wilt, dry root rot etc. in cool season grain legumes (Pande and Sharma, 2011). Under such situations, pre-breeding activities utilizing wild species demand the highest priority and must focus on the identification of new traits better suited to the new environment for developing climate-resilient cultivars with a broad genetic base.

\section{GENOMIC RESOURCES FOR USE IN PRE-BREEDING FOR GRAIN LEGUME IMPROVEMENT}

Significant progress has been made in the development of largescale genomic resources in the last decade for all the three SAT legume crops. Further, coordinated efforts have led to the development of large-scale genomic resources such as molecular markers, construction of comprehensive genetic maps, dense consensus maps and identification of marker-trait associations. Some recent reviews provide in-depth detail on quantity, source and development methods of these resources in these three legumes (see reviews Upadhyaya et al., 2011b; Varshney et al., 2012a, 2013a). Simple sequence repeat (SSR) or microsatellite and single nucleotide polymorphism (SNP) markers are the preferred marker systems especially for genetics and breeding applications. In addition, other genotyping systems such as diversity array technology (DArT) have also become available. A total 
of 13,000-309,052 SSRs markers have become available in chickpea, pigeonpea and groundnut. ICRISAT, in collaboration with DArT Pty Ltd Australia, has developed DArT arrays with 15,360 features for chickpea (Thudi et al., 2011), groundnut and pigeonpea crops (see Varshney et al., 2013a). Although these DArT arrays showed low polymorphism among genotypes of the primary gene pool, they are of great help in monitoring the alien genome introgression in the cultivated species, as been observed for pigeonpea (Mallikarjuna et al., 2011b).

SNP markers are now gaining more importance due to higher abundance and amenability to high-throughput genotyping. Thousands of SNPs were identified using a variety of approaches in chickpea by Hiremath et al. (2011) (26,082 potential SNPs); in pigeonpea by Dubey et al. (2011) (12,141 SNPs) and Varshney et al. (2012a) (28,104 novel SNPs); and in groundnut by University of Georgia (8478 SNPs) (Nagy et al., 2012).

In addition to development of genomic tools essential for breeding applications, there is a great need to develop costeffective genotyping platforms/assays. A range of cost-effective SNP genotyping platforms have become available such as Illumina GoldenGate assays for genotyping 768 SNPs in chickpea by University of California-Davis, USA and 1536-SNPs for groundnut by University of Georgia, USA. In order to provide better genotyping deal for small to medium number of samples $(<500)$, VeraCode assays have been developed for 96-plex and 48plex SNP sets for chickpea and pigeonpea, respectively. Similarly, an alternative genotyping assay (KASPar assay) has been developed by KBiosciences (www.kbioscience.co.uk), which provides flexibility to genotype any number of samples with any number of SNPs. Thus, ICRISAT has developed KASPar assays for 2005 SNPs in chickpea (Hiremath et al., 2012), 1616 SNPs in pigeonpea (Saxena et al., 2012) and 90 SNPs in groundnut (Khera et al., 2013). Besides above mentioned genomic resources and genotyping platforms, draft genome sequences have become available in pigeonpea (Varshney et al., 2012b) and chickpea (Varshney et al., 2013b), while similar efforts are underway in groundnut. The recent availability of the above resources for these three crops has now changed their status from "genomics poor" to "genomics rich" crops.

\section{PRE-BREEDING: PRESENT STATUS AND FUTURE OUTLOOK}

Due to the limited genetic variability available in cultivated germplasm, pre-breeding is gaining importance in most crop improvement programs including wheat (Valkoun, 2001), maize (Nass and Paterniani, 2000), and common bean (Acosta-Gallegos et al., 2007). Recently, under the ICAR-ICARDA collaborative research, efforts are in progress for the improvement of bread wheat, kabuli chickpea, barley, and lentil through pre-breeding and genetic enhancement. At ICRISAT, pre-breeding activities in chickpea, groundnut, and pigeonpea are in progress using promising exotic landraces and wild species as donors along with popular varieties as recipients. The aim is to develop new gene pools with a higher frequency of useful genes, wider adaptability, and a broader genetic base for important agronomic and nutrition-related traits, as well as for resistance/tolerance to important biotic/abiotic stresses. Emphasis is being given to introgress genes for resistance against Ascochyta blight, Botrytis gray mold, and Helicoverpa pod borer in chickpea; for sterility mosaic disease, Phytophthora blight, and pod borer in pigeonpea; and for LLS, peanut stem necrosis disease (PSND), and aflatoxin in groundnut. Among the three SAT legumes, cultivated groundnut has the major need for pre-breeding activities due to a narrow gene pool. The tetraploidization event occurred during the evolution of cultivated groundnut has restricted the exchange of genomic regions between wild relatives and cultivated groups. Fortunately, wide crosses resulted in the development of highly diverse autotetraploids and allotetraploids. Simpson et al. (1993) and Fávero et al. (2006) reported development of three amphiploids using a range of wild AA- and BB- genome species such as $A$. cardenasii, $A$. diogoi, and $A$. batizocoi, A. ipaënsis, A. duranensis, A. gregoryi, and A. linearifolium. In order to diversify the primary gene pool, new amphiploid and autotetraploid groundnuts have been developed at ICRISAT from diploid hybrids such as $A$. magna $\times$ A. valida, A. magna $\times$ A. batizocoi, A. batizocoi $\times$ A. cardenasii, A. batizoco $\times$ A. duranensis, A. ipaënsis $\times$ A. duranensis, A. valida $\times$ A. duranensis, A. duranensis $\times A$. cardenasii, A. kempff mercadoi $\times A$. stenosperma, A. diogoi $\times$ A. cardenasii, A. duranensis $\times$ A. batizocoi, A. cardenasii $\times A$. diogoi, $A$. duranensis $\times$ A. valida, A. duranensis $\times$ A. ipaënsis, A. kempff mercadoi $\times$ A. hoehnei, A. duranensis $\times$ A. batizocoi, and $A$. diogoi $\times A$. cardenasii (Mallikarjuna et al., 2011c). Evaluation of a few of these amphiploids has shown resistance to LLS (Mallikarjuna et al., 2012) and PBND (Shilpa et al., 2013). Using wild species of chickpea and pigeonpea, and synthetic amphiploids in groundnut, GWI lines and advancedbackcross $(\mathrm{AB})$ populations are being developed in the genetic background of elite varieties following marker-assisted selection. (For developing AB-population, a selected wild relative is crossed to an elite cultivar followed by two to three backcrosses with targeted elite cultivar to develop segregating $\mathrm{BC}_{2} \mathrm{~F}_{2}$ or $\mathrm{BC}_{2} \mathrm{~F}_{3}$ populations). Phenotyping and genotyping of these (GWI and $\mathrm{AB}$ ) populations should help in identifying the lines with enhanced genetic base and minimum linkage drag for use in future breeding programs, as well as to find out the markers associated with traits of interest.

\section{INITIATIVES AND HOPE FOR ENRICHING CULTIVATED GENE POOL THROUGH GENOMICS-ASSISTED PRE-BREEDING}

The availability of genomic resources has provided a solution to monitor allele/genome-specific introgression in GWI lines, along with identification of marker-trait association using $A B$ populations. Genomics tools provide efficient tracking for desired and non-desired alien alleles among breeding lines using AB-QTL based breeding approach. Thus, integration of genomic tools with conventional breeding approaches promises to enrich the cultivated gene pool through genomics-assisted pre-breeding. These efforts will help in harnessing the rich diversity of wild relatives possessing superior alleles lost either during domestication or breeding, as well as for exploiting novel alleles. In AB-QTL based breeding approach, genotypic and phenotypic data generated on $\mathrm{AB}$ populations are used for identification of QTLs for several economically important agronomic traits. In addition, it also provides an opportunity to select for QTL-near isogenic lines (NILs) in a short time span along with the development of introgression lines with desired features for use in hybridization programmes. 
As mentioned in previous section, attempts are being made at ICRISAT to introgress stress resistance through AB-breeding approach in grain legumes. In pigeonpea, ICRISAT is in the process of developing two backcross populations (ICPL $87119 \times$ ICPW 29 and ICPL $87119 \times$ ICPW 12) for conducting AB-QTL analysis and their subsequent use in AB-breeding. Among wild relatives used, ICPW 29 belongs to C. cajanifolius while ICPW 12 to $C$. acutifolius species. From the above crosses, $\mathrm{BC}_{2} \mathrm{~F}_{3}$ seeds have been generated for multilocation phenotyping and selection. In groundnut, using two of the above mentioned synthetics, two AB-QTL mapping populations from the crosses between ICGV 91114 (cultivated) and ISATGR 1212 (A. duranensis ICG $8123 \times$ A. ipaënsis ICG 8206, synthetic amphiploid); and between ICGV 87846 (cultivated) and ISATGR 265-5A (A. kempff-mercadoi ICG $8164 \times$ A. hoehnei ICG 8190, synthetic amphiploid) have been developed at ICRISAT. Considerable variability has been observed in these two populations for pod and seed traits (Figure 3). A subset of these two populations has been phenotyped and genotyped with DArT markers to construct genetic maps and conducting AB-QTL analysis. The backcross $\left(\mathrm{BC}_{1} \mathrm{~F}_{1}\right.$ and $\left.\mathrm{BC}_{2} \mathrm{~F}_{1}\right)$ lines carrying the alien genomic segments with maximum recurrent parent genomic regions provided optimal distribution of the synthetic genome introgressions (Foncéka et al., 2009).

In case of chickpea multi-parent advanced generation intercross (MAGIC) populations are being developed to enhance the genetic base. Eight elite lines/cultivars (ICC 4958, ICCV 10,

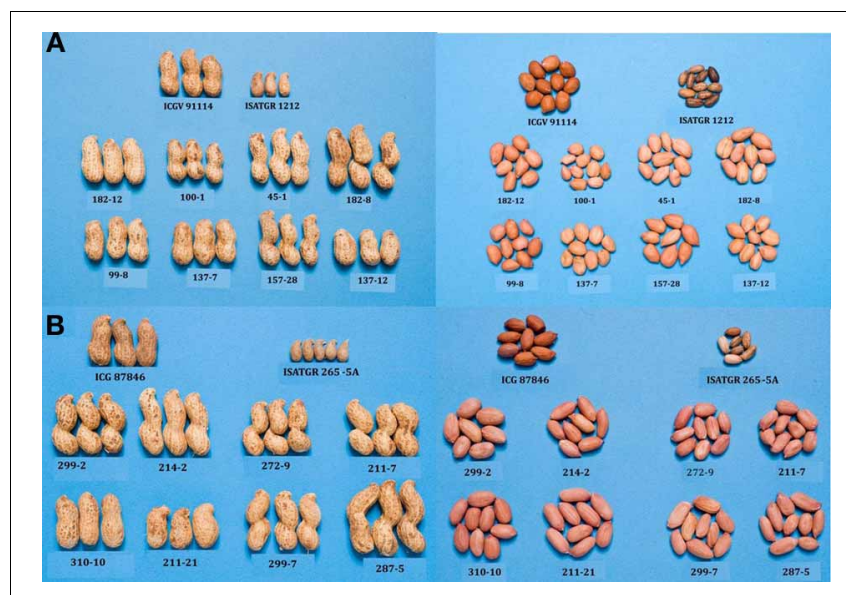

FIGURE 3 | Variability for pod and seed traits in AB-QTL populations derived from using synthetics in crosses between (A) ICGV $91114 \times$ ISATGR 1212 (above) and (B) ICGV 87846 x ISATGR 265-5A (below).

\section{REFERENCES}

Acosta-Gallegos, J., Kelly, J. D., and Gepts, P. (2007). Prebreeding in common bean and use of genetic diversity from wild germplasm. Crop Sci. 47, S44-S59. doi: 10.2135/cropsci2007.04.0008IPBS

Ahmed, K. (2008). Evaluation of Groundnut (Arachis hypogaea L.) Germplasm (Mini core collection). M.Sc. Thesis, University of
Agricultural Sciences, Dharwad; Bangalore.

Ariyanayagam, R. P., Nageshwara, A., and Zaveri, P. P. (1995). Cytoplasmic genic male sterility in interspecific matings of pigeonpea. Crop Sci. 35, 981-985. doi: 10.2135/cropsci1995.0011183X003500040008x

Badami, P. S., Mallikarjuna, N., and Moss, J. P. (1997).
JAKI 9218, JG 11, JG 130, JG 16, ICCV 97105, and ICCV 00108) were selected from Ethiopia, Kenya and India for development of a MAGIC population for desi chickpea. Twenty-eight two-way, 14 four-way and seven eight-way crosses were made to develop this MAGIC population. The best progenies from each generation are being used in various national breeding programs by the breeders. Currently, $1200 F_{6}$ are in the field (crop season 2012-2013). A total of 44 pre-breeding populations have also been developed.

The availability of large number of markers and cost-effective genotyping systems in recent years has ensured that linkage drag has been limited through stringent background selection and monitoring of the wild genomic regions. Hence, keeping in view the low genetic diversity in all the three legume crops, deployment of genomic-assisted pre-breeding is needed for accelerated and efficient enrichment of the cultivated gene pool. This should lead to the incorporation of desired/favorable alleles from wild relatives, increasing genetic gain and ultimately improving yield under adverse conditions and diverse cultural practices.

\section{CONCLUSIONS}

For grain legume improvement, sufficient genetic diversity exists in the form of landraces and wild relatives, which carry several useful genes for cultivar improvement. However, utilization of these resources in breeding programs is time-consuming and resource-demanding. To overcome this, pre-breeding activities should be initiated to generate new genetic variability using promising landraces and wild relatives for use by the breeders in crop improvement programs. Pre-breeding should focus on the continuous supply of useful variability into the breeding pipeline to develop new high-yielding cultivars with a broad genetic base; pre-breeding should not focus on increasing yield. Though pre-breeding is useful to enrich the primary gene pool for cultivar improvement, it is a time-consuming and difficult affair as well. As mentioned by Nass and Paterniani (2000), promising results can only be obtained in 5-10 years depending upon the information available in the beginning of the program. Further, linkage drag associated with utilizing wild relatives makes the prebreeding activities much more cumbersome. Genomic-assisted pre-breeding will help to overcome the linkage drag and will facilitate focused transfer of useful genes/segments from wild relatives for genetic enhancement of grain legumes.

\section{ACKNOWLEDGMENTS}

Authors thank Dr. Nalini Mallikarjuna for sharing the material and Dr. Manish Pandey, Dr. Mahender Thudi, and Dr. Rachit Saxena for their suggestions in finalizing this manuscript.

\footnotetext{
Interspecific hybridization between Cicer arietinum and $C$. Pinnatifidum. Plant Breed. 116, 393-395. doi: 10.1111/j.14390523.1997.tb01019.x

Biabani, A., Carpenter-Boggs, L., Coyne, C. J., Taylor, L., Smith, J. L., and Higgins, S. (2011). Nitrogen fixation potential in global chickpea mini core collection. Biol. Fertil. Soils 47,
}

\author{
679-685. doi: 10.1007/s00374- \\ 011-0574-0 \\ Cantrell, R. P., Christopher, R. \\ Dowswell, C. R., and Paliwal, \\ R. L. (1996). Maize in the Third \\ World. Boulder, CO: Westview \\ Press. \\ Chaturvedi, S. K., and Nadarajan, N. \\ (2010). Genetic enhancement for \\ grain yield in chickpea - accom- \\ plishments and resetting research
}


agenda. Electron. J. Plant Breed. 1, 611-615.

Dalrymple, D. G. (1986). Development and Spread of High-Yielding Wheat Varieties in Developing Countries. 7th Edn. Washington, DC: US Agency for International Development.

Damicone, J. P., Holbrook C. C. Jr. Smith, D. L., Melouk, H. A., and Chamberlin, K. D. (2010). Reaction of the core collection of peanut germplasm to Sclerotinia blight and pepper spot. Peanut Sci. 37, 1-11. doi: 10.3146/PS09-001.1

Dubey, A., Farmer, A., Schlueter, J., Cannon, S. B., Abernathy, B., Tuteja, R., et al. (2011). Defining the transcriptome assembly and its use for genome dynamics and transcriptome profiling studies in pigeonpea (Cajanus cajan L.). DNA Res. 18, 153-164. doi: 10.1093/dnares/dsr007

Dwivedi, S. L., Stalker, H. T., Blair, M. W., Bertioli, D. J., Upadhyaya, H. D., Nielen, S., et al. (2008a). Enhancing crop gene pools with beneficial traits using wild relatives. Plant Breed. Rev. 30, 179-230. doi: 10.1002/9780470380130.ch3

Dwivedi, S. L., Puppala, N., Upadhyaya, H. D., Manivannan, N., and Singh, S. (2008b). Developing a core collection of peanut specific to Valencia market type. Crop Sci. 48, 625-632. doi: 10.2135/cropsci2007.04.0240

FAO. (2010). The Second Report on the State of the World's Plant Genetic Resources for Food and Agriculture. Commission on Genetic Resources for Food and Agriculture (CGRFA). Rome: Food and Agriculture Organization of the United Nations (FAO).

Fávero, A. P., Simpson, C. E., Valls, J. F. M., and Vello, N. A. (2006). Study of the evolution of cultivated peanut through crossability studies among Arachis ipaënsis, A. duranensis, and A. hypogaea. Crop Sci. 46, 1546-1552.

Foncéka, D., Hodo-Abalo, T., Rivallan, R., Faye, I., Sall, M. N., Ndoye, O., et al. (2009). Genetic mapping of wild introgressions into cultivated peanut: a way toward enlarging the genetic basis of a recent allotetraploid.BMC Plant Biol. 9:103. doi: 10.1186/1471-2229-9-103

Franke, M. D., Bennemen, T. B., and Holbrook, C. C. (1999). Identification of resistance to Rhizoctonia limb rot in a core collection of peanut germplasm. Plant Dis. 83, 944-948. doi: 10.1094/PDIS.1999.83.10.944

Frankel, O. H., and Brown, A. H. D. (1984). "Plant genetic resources today: a critical appraisal," in Crop Genetic Resources: Conservation and Evaluation, eds J. H. W. Holden and J. T. Williams (London: George Allen and Unwin LTD), 249-257.

Gaur, P. M., Mallikarjuna, N., Knights, T., Beebe, S., Debouck, D., Mejia, A., et al. (2009). "Gene introgression in grain legumes," in International Conference on Grain Legumes: Quality Improvement, Value Addition and Trade (Kanpur). Gowda, C. L. L., Upadhyaya, H. D., Dronavalli, N., and Singh, S. (2011). Identification of large-seeded high-yielding stable kabuli chickpea germplasm lines for use in crop improvement. Crop Sci. 51, 198-209. doi: 10.2135/cropsci2010.01.0078

Graham, P. H., and Vance, C. P. (2003). Legumes: importance and constraints to greater use. Plant Physiol. 131, 872-877. doi: 10.1104/pp.017004

Hamidou, F., Ratnakumar, P., Halilou, O., Mponda, O., Kapewa, T., Monyo, E., et al. (2011). Selection of intermittent drought tolerant lines across years and locations in the reference collection of groundnut (Arachis hypogaea L.). Field Crops Res. 126, 189-199. doi: 10.1016/j.fcr.2011.10.009

Hammons, R. O. (1970). Registration of Spancross peanuts (Reg. No. 3). Crop Sci. 10, 459-460.

Hannan, R. M., Kaiser, W. J., and Muehlbauer, F. J. (1994). "Development and utilization of the USDA chickpea germplasm core collection," in Agronomy Abstracts 1994, (Madison, WI: ASA), 217.

Hiremath, P. J., Farmer, A., Cannon, S. B., Woodward, J., Kudapa, H., Tuteja, R., et al. (2011). Large-scale transcriptome analysis in chickpea (Cicer arietinum L.), an orphan legume crop of the semi-arid tropics of Asia and Africa. Plant Biotechnol. J. 9, 922-931. doi: 10.1111/j.14677652.2011.00625. $\mathrm{x}$

Hiremath, P. J., Kumar, A., Penmetsa, R. V., Farmer, A., Schlueter, J. A., Chamarthi, S. K., et al. (2012). Large-scale development of costeffective SNP marker assays for diversity assessment and genetic mapping in chickpea and comparative mapping in legumes. Plant Biotechnol. J. 10, 716-732. doi: 10.1111/j.1467-7652.2012.00710.x

Holbrook, C. C., Anderson, W. F., and Pittman, R. N. (1993). Selection of a core collection from the U.S. Germplasm collection of peanut. Crop Sci. 33, 859-861. doi: 10.2135/cropsci1993.0011183X003300040044x
Holbrook, C. C., and Dong, W. (2005). Development and evaluation of a mini core collection for the U.S Peanut Germplasm Collection. Crop Sci. 45, 1540-1544. doi 10.2135/cropsci2004.0368

ICARDA. (1995). "Annual report for 1995," in Germplasm Program Legumes (Aleppo), 210.

Jadhav, D. R., Mallikarjuna, N. Sharma, H. C., and Saxena, K. B. (2012). Introgression of Helicoverpa armigera resistance from Cajanus acutifolius - a wild relative from secondary gene pool of pigeonpea (Cajanus cajan). Asian. J. Agric. Sci. 4, 242-248.

Jiang, H. F., Ren, X. P., Liao, B. S., Huang, J. Q., Lei, Y., Chen, B. Y., et al. (2008). Peanut core collection established in china and compared with ICRISAT mini core collection. Acta Agron. Sin. 34, 25-30. doi 10.3724/SP.J.1006.2008.00025

Jiang, H. F., Ren, X. P., Wang, S. Y., Zhang, X. J., Huang, J. Q., Liao, B. S., et al. (2010). Development and evaluation of peanut germplasm with resistance to Aspergillu flavus from core collection. Acta Agron. Sin. 36, 428-434. doi: 10.3724/SP.J.1006.2010.00428

Kashiwagi, J., Krishnamurthy, L., Singh, S., and Upadhyaya, H. D. (2006). Variation of SPAD chlorophyll meter readings (SCMR) in the mini core germplasm collection of chickpea. J. SAT Agric. Res. 2, 1-3.

Kashiwagi, J., Krishnamurthy, L. Upadhyaya, H. D., and Gaur, P. M. (2008). Rapid screening technique for canopy temperature status and its relevance to drought tolerance improvement in chickpea. J. SAT Agric. Res. 6, 105-104.

Kashiwagi, J., Krishnamurthy, L., Upadhyaya, H. D., Krishna, H., Chandra, S., Vadez, V., et al. (2005). Genetic variability of drought-avoidance root traits in the mini core germplasm collection of chickpea (Cicer arietinum L.). Euphytica 146, 213-222. doi: 10.1007/s10681-005-9007-1

Kashiwagi, J., Upadhyaya, H. D., and Krishnamurthy, L. (2010). Significance and genetic diversity of SPAD chlorophyll meter reading in chickpea germplasm in the semiarid environments. J. Food Legumes 23, 99-105.

Kashiwagi, J., Upadhyaya, H. D., Krishnamurthy, L., and Singh, S. (2007). Identification of highyielding large-seeded kabuli chickpeas with drought avoidance root traits. J. SAT Agric. Res. 3, 1-2.

Kaul, J., Kumar S., and Gurha, S. N. (2007). Evaluation of exotic germplasm of kabuli chickpea. Indian J. Plant Genet. Resour. 20, 160-164.

Khera, P., Sriswathi, M., Roorkiwal, M., Pandey, M., Upadhyaya, H. D., Janila, P., et al. (2013). "Costeffective KASPar assays for SNP genotyping and diversity analysis in the reference set of groundnut," in Plant and Animal Genome XXI Conference. Plant and Animal Genome, (San Diego, CA), P0363.

Kibret, K. T. (2012). Development and utilization of genetic diversity based Ethiopian chickpea (Cicer arietinum L.) germplasm core collection for association mapping. Ph.D. Thesis, International Crops Research Institute for the Semi-Arid Tropics (ICRISAT), Hyderabad.

Krishnamurthy, L., Gaur, P. M., Basu, P. S., Chaturvedi, S. K., Tripathi, S., Vadez, V., et al. (2011a). Large genetic variation for heat tolerance in the reference collection of chickpea (Cicer arietinum L.) germplasm. Plant Genet. Resour. 9, 59-69. doi: 10.1017/S1479262110000407

Krishnamurthy, L., Upadhyaya, H. D., Saxena, K. B., and Vadez, V. (2011b). Variation for temporary water logging response within the mini core pigeonpea germplasm. J. Agric. Sci. $10,1-8$.

Krishnamurthy, L., Turner, N. C., Gaur, P. M., Upadhyaya, H. D., Varshney, R. K., Siddique, K. H. M., et al. (2011c). Consistent variation across soil types in salinity resistance of a diverse range of chickpea (Cicer arietinum L.) genotypes. J. Agron. Crop Sci. 197, 214-227. doi: 10.1111/j.1439-037X.2010.00456.x

Krishnamurthy, L., Kashiwagi, J., Gaur, P. M., Upadhyaya, H. D., and Vadez, V. (2010). Sources of tolerance to terminal drought in the chickpea (Cicer arietinum L.) mini core germplasm. Field Crops Res. 119, 322-330.

Kumar, J., and van Rheenen, H. A. (2000). A major gene for time of flowering in chickpea. J. Hered. 91, 67-68. doi: 10.1093/jhered/91.1.67

Kumar, S., Gupta, S., Chandra, S., and Singh, B. B. (2004). "How wide is genetic base of pulse crops?" in Pulses in new perspective, in Proceedings of the National Symposium on Crop Diversification and Natural Resources Management, eds M. Ali, B. B. Singh, Shiv Kumar and Vishwa Dhar (Kanpur: Indian Society of Pulses Research and Development, Indian Institute of Pulses Research), 211-221.

Kusuma, V. P., Yugandhar, G. Ajay, B. C., Gowda, M. V. C., and Upadhyaya, H. D. (2007). 
"Identification of sources of multiple disease resistance in groundnut (Arachis hypogaea L.) mini core," in ISOR National Seminar (Hyderabad: Directorate of Oilseeds Research), 31-32.

Lulsdorf, M., Mallikarjuna, N., Clarke, H., and Tar'An, B. (2005). "Finding solutions for interspecific hybridization problems in chickpea (Cicer arietinum L.)," in 4th International Food Legumes Research Conference (New Delhi).

Malhotra, R. S., Singh, K. B., Vito, M., Greco, N., and Saxena, M. C. (2002). Registration of ILC 10765 and ILC 10766 chickpea germplasm lines resistant to cyst nematode. Crop Sci. 42, 1756. doi: 10.2135/cropsci2002.1756

Mallikarjuna, N. (1999). Ovule and embryo culture to obtain hybrids from interspecific incompatible pollinations in chickpea. Euphytica 110, 1-6. doi: 10.1023/A:1003621908663

Mallikarjuna, N., Jadhav, D., Reddy, M. V., and Dutta-Tawar, U. (2005). Introgression of Phytophthora blight disease resistance from Cajanus platycarpus into short duration pigeonpea [Cajanus cajan (L.) Millsp.]. Indian J. Genet. 65, 261-263.

Mallikarjuna, N., and Jadhav, D. R. (2008). Techniques to produce hybrids between Cicer arietinum L. $\mathrm{x}$ Cicer pinnatifidum Jaub. Indian J. Genet. 68, 398-405.

Mallikarjuna, N., Jadhav, D. R., Reddy, K., Husain, F., and Das, K. (2012). Screening new Arachis amphidiploids, autotetraploids for resistance to late leaf spot by detached leaf technique. Eur. J. Plant Pathol. 132, 17-21. doi: 10.1007/s10658-011-9859-2

Mallikarjuna, N., Jadhav, D. R., Srikant, S., and Saxena, K. B. (2011a). Cajanus platycarpus (Benth.) Maesen as the donor of new pigeonpea cytoplasmic male sterile (CMS) system. Euphytica 182, 65-71. doi: 10.1007/s10681-011-0488-9

Mallikarjuna, N., Senapathy, S., Jadhav, D. R., Saxena, K. B., Sharma, H. C., Upadhyaya, H. D., et al. (2011b). Progress in the utilization of Cajanus platycarpus (Benth.) Maesen in pigeonpea improvement. Plant Breed. 130, 507-514. doi: $\quad 10.1111 / j .1439-0523.2011$. 01870.x

Mallikarjuna, N., Senthilvel, S., and Hoisington, D. (2011c). Development of new sources of tetraploid Arachis to broaden the genetic base of cultivated groundnut (Arachis hypogaea L.). Genet.
Resour. Crop Evol. 58, 889-907. doi: 10.1007/s10722-010-9627-8

Mallikarjuna, N., Sharma, H. C., and Upadhyaya, H. D. (2007). Exploitation of wild relatives of pigeonpea and chickpea for resistance to Helicoverpa armigera. SAT eJ. 3, 4.

Marshall, D. R. (1989). "Limitations to the use of germplasm collections," in The Use of Plant Genetic Resources, eds A. D. H. Brown, O. H. Frankel, D. R. Marshall, and J. T. Williams (Cambridge: University Press), 105-120.

Meena, H. P., Kumar, J., Upadhyaya, H. D., Bharadwaj, C., Chauhan, S. K., Verma, A. K., et al. (2010). Chickpea mini core germplasm collection as rich sources of diversity for crop improvement. J. SAT Agric. Res. 8, 1-5.

Mikel, M. A., Diers, B. W., Nelson, R. L., and Smith, H. H. (2010). Genetic diversity and agronomic improvement of North American soybean germplasm. Crop Sci. 50, 1219-1229. doi: 10.2135/cropsci2009.08.0456

Moss, J. P., Singh, A. K., Nigam, S. N., Hilderbrand, G. L., Goviden, N., and Ismael, F. M. (1998). Registration of ICGV-SM 87165 peanut germplasm. Crop Sci. 38, 572. doi: 10.2135/cropsci1998.0011183X003800020099x

Nagy, E. D., Guo, Y., Tang, S., Bowers, J. E., Okashah, R. A., Taylor, C. A., et al. (2012). A high-density genetic map of Arachis duranensis, a diploid ancestor of cultivated peanut. BMC Genomics 13:469. doi: 10.1186/1471-2164-13-469

Nass, L. L., and Paterniani, E. (2000). Pre-breeding: a link between genetic resources and maize breeding. Sci. Agric. 57, 581-587. doi: 10.1590/S010390162000000300035

Nigam, S. N., Hildebrand, G. H., Bock, K. R., Ismael, F. M., Govinden, N., Subrahmanyam, P., et al. (1998). Registration of ICGV-SM 85048 peanut germplasm. Crop Sci. 38, 572-573. doi: 10.2135/cropsci1998.0011183X003800020100x

Pande, S., Desai, S., and Sharma, M. (2010). "Impact of climate change on rainfed crop diseases: current status and future research needs," in National Symposium on Climate Change and Rainfed Agriculture, eds B. Venkateswaru, P. K. Mishara, V. U. M. Rao, G. Ravindra Chary, C. H. Srinivasa Rao, K. L. Sharma, K. A. et al. (Hyderabad: Society of Dryland Agriculture, Central Research Institute for Dryland Agriculture), 55-59.
Pande, S., Kishore, G. K., Upadhyaya, H. D., and Rao, J. N. (2006). Identification of multiple diseases resistance in mini core collection of chickpea. Plant Dis. 90, 1214-1218. doi: 10.1094/PD-90-1214

Pande, S., and Sharma, M. (2011). "Climate change and changing scenario of plant diseases in semiarid tropics," in 64th Annual Meeting of the Society and National Symposium on Biology of Infection, Immunity and Disease Control in Pathogen-Plant Interactions (Hyderabad: University of Hyderabad).

Parameshwarappa, S. G., and Salimath, P. M. (2008). Field screening of chickpea genotypes for drought resistance. Karnataka J. Agric. Sci. 21, 113-114.

Parameshwarappa, S. G., Salimath, P. M., Upadhyaya, H. D., Patil, S. S., and Kajjidoni, S. T. (2011a). Genetic divergence under three environments in a mini core collection of chickpea (Cicer arietinum L.). Indian J. Plant Genet. Resour. 24, 177-185.

Parameshwarappa, S. G., Salimath, P. M., Upadhyaya, H. D., Patil, S. S., and Kajjidoni, S. T. (2011b). Genetic variability studies in mini core collections of chickpea (Cicer arietinum L.) under different environments. Indian J. Plant Genet. Resour. $24,43-48$.

Parameshwarappa, S. G., Salimath, P. M., Upadhyaya, H. D., Patil, S. S. Kajjidoni, S. T., and Patil, B. C. (2010). Characterization of drought tolerant accessions identified from the mini core of chickpea (Cicer arietinum L.). Indian J. Genet. Plant Breed. 70, 125-131.

Pouresmael, M., Akbari, M., Vaezi, S., and Shahmoradi, S. (2009). Effects of drought stress gradient on agronomic traits in Kabuli chickpea core collection. Iran. J. Crop Sci. 11, 308-324.

Ramgopal, D., Srivastava, R. K., Pande, S., Rathore, A., Jadhav, D. R., Sharma, M., et al. (2012). Introgression of Botrytis gray mold resistance gene from Cicer reticulatum (bgmrlcr) and C. echinospermum (bgmrlce) to chickpea. Plant Genet. Resour. 1-6.

Rao, N. K., Reddy, L. J., and Bramel, P. J. (2003). Potential of wild species for genetic enhancement of some semi-arid food crops. Genet. Resour. Crop Evol. 50, 707-721. doi 10.1023/A:1025055018954

Reddy, L. J., Nigam, S. N., Moss, J. P., Singh, A. K., Subrahmanyam, P., Mc Donald, D., et al. (1996). Registration of ICGV 86699 peanut germplasm line with multiple disease and insect resistance. Crop Sci. 36, 821. doi: 10.2135/cropsci1996.0011183X003600030072x

Reddy, L. J., Saxena, K. B., Jain, K. C., Singh, U., Green, J. M., Sharma, D., et al. (1997). Registration of high-protein pigeonpea elite germplasm ICPL 87162. Crop Sci. 37, 294. doi: 10.2135/cropsci1997.0011183X003700010066x

Reddy, L. J., Upadhyaya, H. D., Gowda, C. L. L., and Singh, S. (2005). Development of core collection in pigeonpea [Cajanus cajan (L.) Millsp.] using geographic and qualitative morphological descriptors. Genet. Resour. Crop Evol. 52, 1049-1056. doi: 10.1007/s10722-004-6152-7

Rockland, L. B., and Radke, T. M. (1981). Legume protein quality. Food Technol. 35, 79.

Saxena, K. B., Faris, D. G., and Kumar, R. V. (1987). Relationship between seed size and protein content in newly developed high protein lines of pigeonpea. Plant Foods Hum. Nutr. 36, 335-340. doi: 10.1007/BF01892354

Saxena, K. B., and Kumar, R. V. (2003). Development of cytoplasmic nuclear male-sterility system in pigeonpea using C. scarabaeoides (L.) Thours. Indian J. Genet. 63, 225-229.

Saxena, K. B., Kumar, R. V., Dalvi, V. A., Mallikarjuna, N., Gowda, C. L. L., Singh, B. B., et al. (2005). "Hybrid breeding in grain legumesa success story of pigeonpea," in Proceedings of the International Food Legumes Research Conference, eds M. C. Khairwal and H. K. Jain (New Delhi).

Saxena, K. B., Sultana, R., Mallikarjuna, N., Saxena, R. K., Kumar, R. V., Sawargaonkar, S. L., et al. (2010). Male-sterility systems in pigeonpea and their role in enhancing yield. Plant Breed. 129, 125-134. doi: 10.1111/j.1439-0523.2009.01752.x

Saxena, R. K., Varma Penmetsa, R., Upadhyaya, H. D., Kumar, A., Carrasquilla-Garcia, N., Schlueter, J. A., et al. (2012). Large-scale development of cost-effective single-nucleotide polymorphism marker assays for genetic mapping in pigeonpea and comparative mapping in legumes. DNA Res. 19, 449-461. doi: 10.1093/dnares/dss025

Serraj, R., Krishnamurthy, L., and Upadhyaya, H. D. (2004). Screening chickpea mini core germplasm for tolerance to soil salinity. Int Chickpea Pigeonpea Newsl. 11, 29-32. 
Sharma, H. C., Sujana, G., and Rao, D. M. (2009). Morphological and chemical components of resistance to pod borer, Helicoverpa armigera in wild relatives of pigeonpea. Springer, SBM, Dordrecht, Netherlands. Arthropod Plant Interact. 3, 151-161. doi: 10.1007/s11829-009-9068-5

Sharma, M., Pande, S., Pathak, M., Narayana Rao, J., Anil Kumar, P., Madhusudun Reddy, D., et al. (2006). Prevalence of Phytophthora blight of pigeonpea in the Deccan Plateau. J. Plant Pathol. 22, 309-313. doi: 10.5423/PPJ.2006. 22.4.309

Sharma, M., Rathore, A., Mangala, U. N., Ghosh, R., Upadhyaya, H. D., Sharma, S., et al. (2012). New sources of resistance to Fusarium wilt and sterility mosaic disease in a mini core collection of pigeonpea germplasm. Eur. J. Plant Pathol. 133, 707-714. doi: 10.1007/s10658-0129949-9

Sharma, S., Upadhyaya, H. D., Roorkiwal, M., Varshney, R. K., and Gowda, C. L. L. (2013). "Chickpea," in Genetic and Genomic Resources of Grain Legume Improvement, eds M. Singh, H. D. Upadhyaya, and I. S. Bisht (London; Waltham, MA: Elsevier Inc.), 81-104.

Shilpa, K., Sunkad, G., Kurella, S., Marri, S., Padmashree, K., Jadhav, D. R., et al. (2013). Biochemical composition and disease resistance in newly synthesized amphidiploid and autotetraploid peanuts. Food and Nutr. Sci. 4, 169-176. doi: 10.4236/fns.2013.42024

Simpson, C. E., Nelson, S. C., Starr, J., Woodward, K. E., Smith, O. D. (1993). Registration of TxAG-6 and TxAG-7 peanut germplasm lines. Crop Sci. 33 , 1418. doi: 10.2135/cropsci1993.0011183X003300060079x

Simpson, C. E., and Smith, O. D. (1975). Registration of Tamnut 74 peanut (Reg. No. 19). Crop Sci. 15, 603-604. doi: 10.2135/cropsci1975.0011183X001500040050x

Simpson, C. E., and Starr, J. L. (2001). Registration of COAN peanut. Crop Sci. 41, 918. doi: 10.2135/cropsci2001.413918x

Simpson, C. E., Starr, J. L., Church, G. T., Burow, M. D., and Paterson, A. H. (2003). Registration of 'Nema TAM' peanut. Crop Sci. 43, 1561. doi: 10.2135/cropsci2003.1561

Simpson, C. E., Starr, J. L., Nelson, S. C., Woodard, K. E., and Smith, O. D. (1993). Registration of TxAG-6 and TxAG-7 peanut germplasm. Crop Sci. 33, 1418. doi: 10.2135/cropsci1993.0011183X003300060079x
Singh, A. K., Dwivedi, S. L., Pande, S., Moss, J. P., Nigam, S. N., and Sastri, D. C. (2003). Registration of rust and late leaf spot resistant peanut germplasm lines. Crop Sci. 43, 440-441. doi: 10.2135/cropsci2003.0440

Singh, K. B., and Ocampo, B. (1997). Exploitation of wild Cicer species for yield improvement in chickpea. Theor. Appl. Genet. 95, 418-423. doi: $10.1007 / \mathrm{s} 001220050578$

Singh, N. P., Singh, A., Asthana, A. N., and Singh, A. (1999). Studies on inter-specific crossability barriers in chickpea. Ind. J. Pulses Res. 12, 13-19.

Singh, R. P., and Singh, B. D. (1989). Recovery of rare interspecific hybrids of gram Cicer arietinum $\mathrm{x}$ C. cuneatum $\mathrm{L}$. through tissue culture. Curr. Sci. 58, 874-876.

Singh, S., Gumber, R. K., Joshi, N., and Singh, K. (2005). Introgression from wild Cicer reticulatum to cultivated chickpea for productivity and disease resistance. Plant Breed. 124, 477-480. doi: 10.1111/j.14390523.2005.01146.x

Srivastava, N. (2010). Identification of Contrasting Parental Material for Salinity Tolerance Based on Morphological, Physiological, and Biochemical Study and Molecular Diversity by SSR Molecular Markers in Groundnut (Arachis hypogaea). Ph.D., Thesis, Jawaharlal Nehru Technological University, Hyderabad.

Srivastava, N., Vadez, V., Upadhyaya, H. D., and Saxena, K. B. (2006). Screening for intra and interspecific variability for salinity tolerance in pigeonpea (Cajanus cajan) and its wild species. J. SAT Agric. Res. 2, 12.

Subbarao, G. V., Johansen, C., Kumar Rao, J. V. D. K., and Jana, M. K. (1990). Salinity tolerance in F1 hybrids of pigeonpea and a tolerant wild relative. Crop Sci. 30, 785-788. doi: 10.2135/cropsci1990.0011183X003000040005x

Sujana, G., Sharma, H. C., and Rao, D. M. (2008). Antixenosis and antibiosis components of resistance to pod borer Helicoverpa armigera in wild relatives of pigeonpea. Int. J. Trop. Insect Sci. 28, 191-200.

Tar'an, B., Warkentin, T. D., Vandenberg, A., and Holm, F. A. (2010). Variation in chickpea germplasm for tolerance to imazethapyr and imazamox herbicides. Can. J. Plant Sci. 90, 139-142.

Thudi, M., Bohra, A., Nayak, S. N., Varghese, N., Shah, T. M., Penmetsa, R. V., et al. (2011). Novel SSR markers from BAC-end sequences, DArT arrays and a comprehensive genetic map with 1, 291 marker loci for chickpea (Cicer arietinum L.). PLoS ONE 6:e27275. doi: 10.1371/journal.pone.0027275

Tikka, S. B. S., Parmar, L. D., and Chauhan, R. M. (1997). First record of cytoplasmic-genic male sterility system in pigeonpea (Cajanus cajan (L.) Millsp.) through wide hybridization. Gujarat Agric. Univ. Res. J. 22, 160-162.

Upadhyaya, H. D. (2005). Variability for drought resistance related traits in the mini core collection of peanut. Crop Sci. 45, 1432-1440. doi: $10.2135 /$ cropsci2004.0389

Upadhyaya, H. D. (2008). Crop Germplasm and wild relatives: a source of novel variation for crop improvement. Korean J. Crop Sci. $53,12-17$.

Upadhyaya, H. D., and Ortiz, R. (2001). A mini core subset for capturing diversity and promoting utilization of chickpea genetic resources in crop improvement. Theor. Appl. Genet. 102, 1292-1298. doi: 10.1007/s00122-001-0556-y

Upadhyaya, H. D., Bramel, P. J., Ortiz, R., and Singh, S. (2002). Developing a mini core of peanut for utilization of genetic resources. Crop Sci. 42, 2150-2156. doi: 10.2135/cropsci2002.2150

Upadhyaya, H. D., Dronavalli, N., Gowda, C. L. L., and Singh, S. (2011a). Identification and evaluation of chickpea germplasm for tolerance to heat stress. Crop Sci. 51, 2079-2094. doi: 10.2135/cropsci2011.01.0018

Upadhyaya, H. D., Thudi, M. Dronavalli, N., Gujaria, N., Singh, S., Sharma, S., et al. (2011b). Genomic tools and germplasm diversity for chickpea improvement. Plant Genet. Resour. 9, 45-48. doi: 10.1017/S1479262110000468

Upadhyaya, H. D., Salimath, P. M., Gowda, C. L. L., and Singh, S. (2007a). New early-maturing germplasm lines for utilization in chickpea improvement. Euphytica 157, 195-208. doi: 10.1007/s10681-007-9411-9

Upadhyaya, H. D., Dwivedi, S. L., Gowda, C. L. L., and Singh, S. (2007b). Identification of diverse germplasm lines for agronomic traits in a chickpea (Cicer arietinum L.) core collection for use in crop improvement. Field Crops Res. 100, 320-326. doi: 10.1016/j.fcr.2006.08.008

Upadhyaya, H. D., Mallikarjuna Swamy, B. P., Goudar, P. V. K., Kullaiswamy, B. Y., and Singh, S. (2005). Identification of diverse groundnut germplasm through multienvironment evaluation of a core collection for Asia. Field Crops Res. 93, 293-299. doi: 10.1016/j.fcr.2004.10.007

Upadhyaya, H. D., Sharma, S., and Dwivedi, S. L. (2012a). "Arachis," in Wild Crop Relatives: Genomic and Breeding Resources, Legume Crops and Forages, ed C. Kole (Berlin; Heidelberg: Springer-Verlag Publisher), 1-19.

Upadhyaya, H. D., Mukri, G., Nadaf, H. L., and Singh, S. (2012b). Variability and stability analysis for nutritional traits in the mini core collection of peanut. Crop Sci. 52, 168-178. doi: 10.2135/cropsci2011.05.0248

Upadhyaya, H. D., Bramel, P. J., and Singh, S. (2001a). Development of a chickpea core collection using geographic distribution and quantitative traits. Crop Sci. 41, 206-210. doi: 10.2135/cropsci2001.411206x

Upadhyaya, H. D., Ortiz, R., Bramel, P. J., and Singh, S. (2001b). "Development of Asia region groundnut core collection," in Paper Presented in the Diamond Jubilee Symposium on Hundred Years of Post-Mendelian Genetics - Retrospect and Prospects, Indian Agricultural Research Institute (New Delhi), 43-44.

Upadhyaya, H. D., Ortiz, R., Bramel, P. J., and Singh, S. (2003). Development of a groundnut core collection using taxonomical, geographical and morphological descriptors. Genet. Resour. Crop Evol. 50, 139-148. doi: 10.1023/A:1022945715628

Upadhyaya, H. D., Reddy, L. J., Gowda, C. L. L., Reddy, K. N., and Singh, S. (2006a). Development of a mini core subset for enhanced and diversified utilization of pigeonpea germplasm resources. Crop Sci. 46, 2127-2132. doi: 10.2135/cropsci2006.01.0032

Upadhyaya, H. D., Reddy, L. J., Gowda, C. L. L., and Singh, S. (2006b). Identification of diverse groundnut germplasm: sources of early-maturity in a core collection. Field Crops Res. 97, 261-267. doi: 10.1016/j.fcr.2005.10.010

Upadhyaya, H. D., Reddy, L. J., Gowda, C. L. L., and Singh, S. (2009). Phenotypic diversity in cold-tolerant peanut (Arachis hypogaea L.) germplasm. Euphytica 165, 279-291. doi: 10.1007/s10681-008-9786-2

Upadhyaya, H. D., Sharma, S., Reddy, K. N., Saxena, R., Varshney, R. K., and Gowda, C. L. L. (2013). "Pigeonpea," in Genetic and Genomic Resources of Grain Legume 
Improvement, eds $\mathrm{M}$. Singh, $\mathrm{H}$. D. Upadhyaya, and I. S. Bisht (London; Waltham, MA: Elsevier Inc.), 181-198.

Upadhyaya, H. D., Yadav, D., Dronavalli, N., Gowda, C. L. L., and Singh, S. (2010). Mini core germplasm collection for infusing genetic diversity in plant breeding programs. Electron. J. Plant Breed. 1,1294 .

Vadez, V., Krishnamurthy, L., Serraj, R., Gaur, P. M., Upadhyaya, H. D., Hoisington, D. A., et al. (2007). Large variation in salinity tolerance in chickpea is explained by differences in sensitivity at reproductive stage. Field Crops Res. 104, 123-129. doi: 10.1016/j.fcr.2007.05.014

Valkoun, J. J. (2001). Wheat prebreeding using wild progenitors. Euphytica 119, 17-23. doi: 10.1023/A:1017562909881

Varshney, R. K., Kudapa, H., Roorkiwal, M., Thudi, M., Pandey, M. K., Saxena, R. K., et al. (2012a). Advances in genetics and molecular breeding of three legume crops of semi-arid tropics using next-generation sequencing and high-throughput genotyping technologies. J. Biosci. 37, 811-820. doi: 10.1007/s12038-012-9228-0

Varshney, R. K., Chen, W., Li, Y., Bharti, A. K., Saxena, R. K., Schlueter, J. A., et al. (2012b). Draft genome sequence of pigeonpea (Cajanus cajan), an orphan legume crop of resourcepoor farmers. Nat. Biotechnol. 30, 83-89. doi: $10.1038 / \mathrm{nb}$ t.2022

Varshney, R. K., Mohan, S. M., Gaur, P. M., Gangarao, N. V. P. R., Pandey, M. K., Bohra, A., et al. (2013a). Achievements and prospects of genomics-assisted breeding in three legume crops of the semi-arid tropics. Biotechnol. Adv. doi: 10.1016/j.biotechadv. 2013.01.001. [Epub ahead of print].

Varshney, R. K., Song, C., Saxena, R. K., Azam, S., Yu, S., Sharpe, A. G., et al. (2013b). Draft genome sequence of chickpea (Cicer arietinum) provides a resource for trait improvement. Nat. Biotechnol. 31, 240-246. doi: 10.1038/nbt.2491

Vellve, R. (1992). Saving the Seeds: Genetic Diversity and European
Agriculture. London: Earthscan Publication.

Verma, M. M., Ravi, and Sandhu, J. S. (1995). Characterization of the interspecific cross Cicerarietinum, L. $\mathrm{x}$ C. judaicum (Boiss.). Plant Breed. 114, 549-551. doi: 10.1111/j.14390523.1995.tb00856.x

Verma, M. M., Sandhu, J. S., Rrar, H. S., and Brar, J. S. (1990). Crossability studies in different species of Cicer(L.). Crop Improv. 17, 179-181.

Wanjari, K. B., Patil, A. N., Manapure, P., Manjaya, J. G., and Manish, P. (2001). Cytoplasmic male-sterility with cytoplasm from Cajanus volubilis. Ann. Plant Physiol. 13, 170-174.

Yadav, S. S., Kumar, J., Turner, N. C., Berger, J., Redden, R., McNeil, D. et al. (2004). Breading for improved productivity, multiple resistance and wide adaptation in chickpea (Cicer arietinum L.). Plant Genet. Resour. Charact. Util. 2, 181-187. doi: 10.1079/PGR200448

Conflict of Interest Statement: The authors declare that the research was conducted in the absence of any commercial or financial relationships that could be construed as a potential conflict of interest.

Received: 03 June 2013; paper pending published: 21 June 2013; accepted: 23 July 2013; published online: 20 August 2013.

Citation: Sharma S, Upadhyaya HD, Varshney RK and Gowda CLL (2013) Pre-breeding for diversification of primary gene pool and genetic enhancement of grain legumes. Front. Plant Sci. 4:309. doi: 10.3389/fpls.2013.00309

This article was submitted to Plant Genetics and Genomics, a section of the journal Frontiers in Plant Science. Copyright (๑) 2013 Sharma, Upadhyaya, Varshney and Gowda. This is an openaccess article distributed under the terms of the Creative Commons Attribution License (CC BY). The use, distribution or reproduction in other forums is permitted, provided the original author(s) or licensor are credited and that the original publication in this journal is cited, in accordance with accepted academic practice. No use, distribution or reproduction is permitted which does not comply with these terms. 